\title{
Information Impact
}

\section{Remuneration and Librarianship as a Choice of Career}

Imaobong Ndifreke Obot

University of Uyo, Nigeria

Nse Emmanuel Akwang

Akwa Ibom State University, Nigeria

\section{Chinyere Priscilla Okoro}

Alvan Ikoku Federal College of Education, Nigeria.
Information Impact: Journal

of information and

knowledge management

2018, Vol. 9 (3) Pg. 161-170

ISSN: $2141-4297$ (print)

ISSN: 2360 - 994X (e-version)

\begin{abstract}
The study investigated remuneration and its relationship with librarianship as a career choice. The survey design was used for the study. The hypothesis was tested using the Pearson Product Moment Correlation (PPMC) statistical technique and the relationship was established to be significant at 0.05 level of significance. Remuneration had a relatively low positive correlation (0.32) between remuneration and librarianship as a career choice. The study concluded that remuneration, though positively related, is not a strong determinant of Librarianship as choice of career. The study therefore recommended among other things that outside salaries, government should provide fringe benefits to librarians in academic institutions to enhance satisfactory performance thereby motivating others to join the library profession.
\end{abstract}

\section{Keywords: Remuneration, Library Profession, Career, Tertiary}

\section{Introduction}

A profession is generally agreed to be based on a systematic intellectual knowledge communicated through planned educational process. Entry into a profession is limited to people who have undergone some specified educational training or programme (Sally in Etim, 2010). In view of this monopoly, professions generally exercise some control over training, certification and accreditation of courses, registration and standards of practice. In view of this, Lawal (2002) highlighted five criteria for the determination of professionalism to include the knowledge-base theory, the skill factor, existence of a professional organization, public recognition and a service orientation. Observing these characteristics, one can conclude that the library profession is a profession already rated by public view. However, no other profession is quite so troubled by the murky identification of the educated practitioner. Thus, the clerk at the circulation desk is often called a librarian, a mistake made so often. 
In a similar view, Aguolu and Aguolu (2002) identified the essential elements of a profession as "requiring specialized body of knowledge and skill required during a prolonged period of education and training, existence of a professional association which defines admission into the profession". The authors also argued that "the respect and recognition accorded a profession by society are largely determined by the public understanding and acceptance of the importance of the profession in that society". This further shows that the status of the library profession is determined by the society's perception of the nature of librarians' duties and social responsibilities. Even though the society fails to realize these duties, librarians are often expected to take part in community affairs, cooperating in the preparation of exhibits, presenting book reviews and explaining library use to community organizations. As professionals, they are also expected to use their wealth of knowledge in developing the cultural taste of library patrons. This feature of a profession is an index for its choice by librarians in tertiary institutions.

When compared to older professions like Law and Medicine in any society, the consensus of opinions among experts in library and information science is that librarians and information scientists still have a problem of recognition and respect (Aguolu and Aguolu, 2002; Ugah and Ntui, 2005). Thus the problem of status of the library profession is not restricted to any one group of librarians. It is generally agreed that the library is the heart of the university and therefore, the quality of the university is reflected by the quality of the library. Yet it is widely observed that most faculty members are unable to distinguish between professional library staff and their various subordinate staff members working in the university library.

A librarian is an information professional trained in library and information science, which is the organization and management of information services or materials for those with information needs. Typically, Librarians may be categorized as public, school, special, independent or academic librarians. Some librarians are independent entrepreneurs working as information specialists, cataloguers, indexers, publishers and other professional specialized capacities. The term "librarian" is used often and incorrectly to refer to anyone who works in a library. Para-professional or clerical staff working in a library is more properly referred to as library clerks, library assistants or some equivalent title. In a library, there are many positions other than that of librarians, such positions include library associate, clerk, and shelver. Professional positions such as manager, director or administrator are often filled by professional librarians. In these positions, the worker may be given the title administrator, director, manager or librarian.

Every individual who has attained a certain level of education is encouraged to set high aspirations for himself and to work hard to achieve these goals. People are increasingly made to become aware of the prestige that goes along with a successful career choice. As such, professional variables like interest, nature of library work, education, remuneration, public recognition and service orientation are used as pressures to induce individuals into predetermined 
professions. Though individuals are indecisive about choosing a career in librarianship, the field of information services has prominent professionals. This group of professionals is referred to as librarians and the greater bulk of their work lies in helping others find information and select materials best suited to their needs.

Librarians as professionals also work in public, academic, special and school libraries, media centres, corporations and government agencies. They are key personnel wherever information materials are catalogued and stored; they also help make access to these reference materials possible. Library and information services are however expanding in Nigeria. Consequently, professional personnel are required as the basis for effective and efficient library services. The rapid changes in the economy of Nigeria have brought the importance of career choice into sharp focus. As the country's economy continues to expand following upsurge in technological advancements, the nature of many jobs changes and the techniques of its provision to individuals become important. Therefore, the variables that influence career choices in the library profession should be viewed as dynamic and susceptible to changes depending on the economy. Library and information services are however expanding in Nigeria. Consequently, professional personnel are required as the basis for effective and efficient library services. Planning for the future supply of this cadre of staff as well as adequate utilization of the present manpower will depend on the number of people who choose to join the library profession.

\section{Statement of the Problem}

A wrong choice of career often contributes to low productivity, lack of job satisfaction and uneasiness at work. In choosing a career therefore, it is of cardinal importance to examine the factors that may relate with such a decision. In our society today, it is common place to have people begin to factor career choices based on interest, public recognition, service orientation, job specification, and opportunity for advancement, remuneration and so on. Motives and reasons for a career choice have been extensively researched. This development however does not fill the void regarding the dearth of literature in remuneration as a motivation for choice of the library profession as a career. In a way, most of what motivates individuals to enter a profession also accounts for the challenges and difficulties encountered in making and implementing such career decisions (Etim, 2010). Consequently, this study emphasizes the fundamental query on whether remuneration is a significant factor in choice of Librarianship as a career in tertiary institutions.

\section{Objectives of the Study}

The specific objective of the study is to:

1. ascertain the relationship between remuneration and librarianship as a career choice

\section{Research Question}

The research question below was formulated to guide the study: 
1. What relationship exists between remuneration and librarianship as a career choice

\section{Hypothesis}

The hypothesis which was stated in the null form was formulated to guide the study thus:

1. Remuneration has no significant relationship with librarianship as choice of career

\section{Literature Review}

Remuneration is one of the professional variables which influence librarians' choice of library profession as a career. The way individuals perceive remuneration motivates their choice of library profession as a career, particularly in academic institutions. According to Akintoye (2000), "money remains the most significant influence on choice of career". Money possesses significant motivating power in as much as it symbolizes intangible goals like security, power, prestige and a feeling of accomplishment and success. Katz, in Sinclair et al. (2005), demonstrated the motivational power of money through the process of job choice. The author further explained that money has the power to attract, retain and motivate individuals towards career choice and higher performance. For instance, if a librarian or information professional has another job offer which has identical job characteristics with his current job, but greater financial reward, that worker would in all probability be motivated to accept the new job offer.

The pay package of the librarian naturally depends on the economic, social and cultural conditions in a given country. A librarian who cannot get sufficient wage will be faced with the problem of maintaining his or her family's life. This problem puts individuals far from choosing a career in librarianship. According to Lawal (2002), the grading definition of librarians according to salary scales and library position is one of the most significant factors of status concerns. Usually, the principles guiding any grading exercise are followed strictly in academic communities where appropriate factors are taken into account. However, in the public and government sectors of the profession, the librarian's salary is closely related to the scales of clerks. This situation is universally undesirable. The author stressed further that in the U.K., the Library Association's Manpower and Conditions of Service Committee in liaison with the Joint Negotiating Committee (JNC) have jointly conducted a national review of the existing grading prescription for librarians so as to determine whether it is relevant to the changing needs of library service. Lawal emphasized concern for the local authorities who seem to place librarians' below the minimum scales recommended by the profession. This situation, he implies, has great implication on librarians' preference for library profession as a career.

Low wages and lack of status and social security affect one's choice of a profession. Job satisfaction cannot be talked of where there is absence of motivation in terms of higher wages. 
Good pay for the librarian who has an important place in the information society can affect the quality of the service he renders and can also motivate a librarian's choice of the profession. St. Lifer in Etim (2010) reported the results of a survey of librarians' perception of their jobs. These included compensation and benefits, advancement opportunities and technological challenges. The result showed that salaries and benefits are related to job satisfaction. Horenstein in Etim (2010) similarly reported on a study that examined the job satisfaction of academic librarians as it is related to faculty status. The finding indicated that librarians with academic rank were more satisfied than non-faculty groups. Predictors of their choice of library profession which ultimately informed their satisfaction include perceptions of participation and salary.

In terms of issues related to salary, benefits and other job attractions, researchers confirm that few individuals have been motivated to choose library and information science as a career. Therefore Nwahunanya (2000) in his study on gender and adolescents' choice of science-related careers in Abia state senior secondary schools, found out that such careers "give more money" ie. job attraction with 71 and 54 levels of agreement for boys and girls respectively. This study corroborates the study by Anderson and Straka (2001) which found salary as an influential factor second to public image accorded a particular profession. This study shows that in every profession, job attraction in the form of wage incentives, is a major factor that triggers individual's preference for it. This is basically true because people prefer such careers that convey high social prestige and power', thus the respondents have no other options in a society where the desire to earn money has become a serious competitive business.

On the contrast however, some studies have examined remuneration as being the least factor considered in choice of career. Therefore, Houdyshell, Robles and Hua in Lo et al (2016) in their study on what motivated librarians in their choice of career in Library and Information Science (LIS), found out that apart from the most influential factors which included opportunity to serve others, intellectual challenges and the nature of the LIS work itself, librarians were generally displeased with their professional status, salary and the repetitive duties. However, their study also showed that only an inconsiderable percentage of the respondents acknowledged remuneration as a significant motivating factor in the choice of LIS. Similarly, Ard et al (2006) conducted a survey of Master of Library Science Students at the University of Alabama to examine their motivations in career choice in LIS, especially as it has to do with their views of the job market and their preferred areas of LIS work after graduation. Their responses indicated that the opportunity to get a job that they considered interesting was far more important than financial compensations or professional and social prestige. Generally, salaries for librarians are meager, thus the low public recognition of the profession in the society and subsequent lack of choice of it as a career.

Salaries for library professionals vary depending on a number of factors including the type of library (i.e. public, school, academic, etc.), population of the community served, region of the country, years of experience, etc. (ALA, 2018). The authors further stated that in general, salaries are usually higher in academic libraries (vs. public), large metropolitan areas (vs. rural). 
In line with the above assertion, Tella, Ayeni and Popoola (2007) analysed job satisfaction which could lead to career choice in the field of LIS among Oyo state academic librarians. Findings of the study revealed that respondents in academic librarians with less experience were generally satisfied with their job and could choose to work in the library over and over again. This finding was as a result of the fact that even with less experience, their take home pay and other working conditions was something to write home about. There are fringe benefits associated with academic library work that can be an influence to the preference for the profession as a career (Hudson in Etim, 2010). Therefore such factors as attractive salary, good conditions of service, and job security especially as it has to do with library work in higher academic institutions can promote librarianship as a choice of career.

\section{Methodology}

The survey research design was adopted for this study because the study deals with homogenous subjects and the information required for this study is discrete. The population of the study comprised all the 86 professionally trained librarians in the 8 tertiary institutions in Akwa Ibom and Cross River States, chosen for the study. The tertiary institutions that formed the population of the study were eight in number as shown in the table below:

Table 1: $\quad$ Population as Classified by Tertiary Institutions

\begin{tabular}{|l|l|l|l|}
\hline Tertiary institutions & $\begin{array}{l}\text { Population } \\
\text { of librarians }\end{array}$ & $\begin{array}{l}\text { Sample of } \\
\text { librarians }\end{array}$ & Percent (\%) \\
\hline University of Uyo, Uyo & 25 & 25 & 100 \\
\hline College of Education, Afaha Nsit & 6 & 6 & 100 \\
\hline Akwa Ibom State University & 7 & 7 & 100 \\
\hline Maritime Academy, Oron & 2 & 2 & 100 \\
\hline Akwa Ibom State Polytechnic, Ikot Osurua & 2 & 2 & 100 \\
\hline University of Calabar, Calabar & 36 & 36 & 100 \\
\hline Cross River State University of Technology & 7 & 7 & 100 \\
\hline College of Education, Akamkpa & 1 & 1 & 100 \\
\hline Total & $\mathbf{8 6}$ & $\mathbf{8 6}$ & $\mathbf{1 0 0}$ \\
\hline
\end{tabular}

Administrative Records of each Institution (2015)

The total population of 86 librarians was used as sample for the study. The use of the entire population as sample was based on the fact that the population is small and accessible. 
This implies that the census technique was employed whereby all members of the population will be used. Thus the census size was 86 librarians. The instrument used for data collection for this study was a researcher-developed questionnaire titled Remuneration and Librarianship as a Career Choice Questionnaire (RLCCQ). The questionnaire was designed to measure the relationship between remuneration and choice Librarianship as a Career in Akwa Ibom and Cross Rivers States.

Section A focused on personal data of respondents, institution, designation, gender and professional qualification. The name of the respondents was not required in order to encourage objectivity in the responses given. Section B consisted had items on the relationship between remuneration and librarians' preference for the library profession. All items in this section contained the five points Likert-Scale with Strongly Agree (SA), Agree (A), Undecided (U), Disagree (D) and Strongly Disagree (SD) responses. For face and content validity, the questionnaire was submitted to the researcher's supervisor and other research experts in the University of Uyo in the areas of library and information science, for face, construct and content validity. Their suggestions and modifications were incorporated into the final draft of the instrument. To test the reliability of the instrument, 20 copies of the questionnaire was given to 20 librarians randomly sampled outside the area of study. The responses obtained were analysed using frequency count and the data obtained were used to determine the reliability of the instrument using Cronbach's alpha reliability coefficient formula and this yielded an overall coefficient index of 0.85. All the hypotheses were tested using Pearson Product Moment Correlation Coefficients (PPMC) at 0.05 alpha level.

\section{Findings and discussion}

\section{Hypothesis One: Remuneration has no significant relationship with librarianship as a career choice}

Remuneration has no significant relationship with librarianship as a career. In hypothesis one, the independent variable is remuneration, and the dependent variable is the librarians' choice of library profession. The hypothesis was tested using the Pearson Product Moment Correlation Coefficient (PPMC) as shown in Table 2

Table 2: Pearson Product Moment Correlation Coefficient (PPMC) Summary of Analysis on Remuneration and Librarianship as a Career Choice $(\mathrm{N}=86)$

\begin{tabular}{lcccccc}
\hline Variables & $\sum \mathbf{X}$ & $\sum \mathbf{X}^{2}$ & $\sum \mathbf{X Y}$ & $\mathbf{r}_{\mathrm{xy}}$ (Cal) & $\mathbf{d f}$ & $\mathbf{r}_{\mathrm{xy} \text { (Crit) }}$ \\
& $\sum \mathbf{Y}$ & $\sum \mathbf{Y}^{\mathbf{2}}$ & & & & \\
\hline Remuneration (X) & 752 & 6752 & 6744 & $0.32^{*}$ & 84 & .20 \\
Librarians' choice of library profession (Y) & 768 & 6904 & & & & \\
& & & & & &
\end{tabular}


$*$ Significant at $\mathrm{p}<.05$ alpha

The results in Table 2 show that the calculated correlation coefficient, rxy(cal), for the relationship between remuneration and librarians' choice of library profession is 0.32 while its corresponding table value at df 84 and $\mathrm{p}=0.05$ alpha ( $\operatorname{rxy}(\mathrm{crit})$ ), is 0.20 . The calculated value of 0.32 is greater than the critical value of 0.20 . This finding indicates that the relationship between remuneration and the librarians' choice of the profession is statistically significant. That is, remuneration has a significant relationship. The results in Table 2 show that the calculated

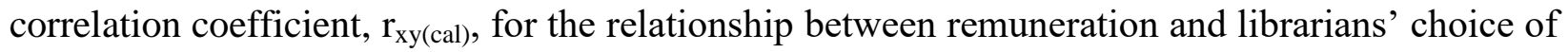
library profession is 0.32 while its corresponding table value at $\mathrm{df} 84$ and $\mathrm{p}=0.05$ alpha $\left(\mathrm{r}_{\mathrm{xy}}\right.$ (crit) $)$, is 0.20 . The calculated value of 0.32 is greater than the critical value of 0.20 . This finding indicates that the relationship between remuneration and the librarians' choice of the profession with librarians' choice of library profession. Null hypothesis four was therefore rejected. The positive correlation index observed indicates that the majority of the librarians in tertiary institutions chose the profession because of its attractive salary.

\section{Discussion of Findings}

It was observed from the result in Table 2 that a low positive correlation (index $=0.32$ ) exists between remuneration and librarians' choice of librarianship as a career. This implies that, though positively correlated, remuneration is not a very strong factor in librarians' choice of their career. This observation, however, is a departure from Akintoye (2002) assertion that money remains the most significant influence on career choice. This study deviates from St. Lifer and Horenstein study in Etim (2010), Sinclair et al (2005), Nwahunanya (2000) and Anderson and Straka (2001) studies which found salary as an influential factor in the choice of any career. This study is however in agreement with Hudson's assertion in Etim (2010) that aside from salary, other fringe benefits associated with academic library work, such as status and social security attract librarians to their profession.

This study is however in conformity with some studies that have examined remuneration as being the least factor considered in choice of careers. These studies include Houdyshell, Robles and Hua in Lo et al (2016) who in their study on what motivated librarians in their choice of career in Library and Information Science (LIS), found out that apart from the most influential factors which included opportunity to serve others, intellectual challenges and the nature of the LIS work itself, librarians were generally displeased with their professional status, salary and the repetitive duties. Similarly, Ard et al (2006) in their study, indicated that the opportunity to get a job that respondents considered interesting was far more important than financial compensations or professional and social prestige. 


\section{Major Findings}

There is a relatively low positive correlation between remuneration and librarianship as a choice of career (index $=0.32$ ). This indicates that remuneration is not a very strong factor in librarianship as a choice of career.

\section{Conclusion}

Based on the findings in this study, one can conclude that, remuneration, though positively related, is not a strong determinant of librarians' choice of profession. The implication of the findings is that we live in a society where the country's economy continues to expand following upsurge in technological advancements. As a result, librarians seek for many ways to enhance their service delivery through these multifaceted technologies. Therefore, as the nature of the library profession changes, the techniques of librarians' provision of services to users become much more important than the financial gains made.

\section{Recommendations}

The study found that there exist a low positive correlation between remuneration and librarianship as a career choice. Based on this finding, this researcher recommends that:

1. Outside salaries, government should provide fringe benefits to librarians in academic institutions to enhance satisfactory performance thereby motivating others to join the library profession.

2. Since the library profession is not a money making venture but a service oriented profession, employers should ensure that applicants are made to undergo both written and oral examinations in order to ascertain that those aspiring to join the profession should have investigative and social personalities which will thus come to bear in the diligent discharge of their duties.

3. Librarians in tertiary institutions could spark interest in career choice and bring forth new ideas in the profession through book discussion groups, career choice counseling, and lectures, homework help to students as well as internet use and online databases navigation.

\section{References}

Aguolu, C. C. \& Aguolu, I. E. (2002). Libraries and Information Management in Nigeria. Maidugari: Ed-Linform. pp. 427- 439.

Akintoye, I. R. (2000). The Place of Financial Management in Personnel Psychology. A paper presented as part of personnel psychology. Guest Lecture Series, Department of Guidance and Counselling, University of Ibadan, Nigeria. 
Anderson, L. S. \& Straka, V. (2001). Engineering: a Career for Young Women. Toronto: Ryerson University, pp.54-55.

Etim, I. A (2010). Professional Variables and Librarians' Choice of Library Profession as a Career in Tertiary Institutions in Akwa Ibom and Cross River States of Nigeria. Unpublished Master of Library Science (MLS) Thesis, University of Uyo of Uyo.

Lawal, O. O. (2002). The Library Profession in Nigeria. Calabar: University of Calabar Press, Chapters 1-5.

Nwahunanya, C. I. (2000).Gender and Adolescents' Choice of Science Related Careers. Nigerian Journal of Professional Studies in Education. 8(2): 44-49.

Sinclair, R. R., Tucker, J. S., Cullen, J. C. \& Wright, C. (2005). Performance Differences among Four Organizational Commitment Profiles. Journal of Applied Social Psychology, 78: 774 -780 .

Tella, A., Ayeni, C. O. \& Popoola, S. A. (2007). Work motivation, job satisfaction and organizational commitment of library personnel in academic and research libraries in oyo state, Nigeria. Library Philosophy and Practice.(April) 1-6 from http//www.webpages.uidaho.edu/ mbolin/tella2.

Ugah, A. D. \& Ntui, A. I. (2005). Challenges in the Management of Modern Public Libraries. Unpublished Ph. D. Seminar, University of Uyo, Uyo, Nigeria. 